\title{
Léčba selenem u tyreopatii - editorial
}

\author{
Zdeněk Fryšák \\ III. interní klinika - nefrologická, revmatologická a endokrinologická LF UP a FN Olomouc
}

Komentář k | Editorial on

Sotak Š. Liečba selénom u tyreopatií. Vnitř Lék 2017; 63(12): 949-951.

Selen je považován za významný antioxidační činitel se vztahem $\mathrm{k}$ autoimunitním reakcím. Podstatné je to, že ze všech tkání v organizmu je to především štítná žláza, v níž je selen, přepočteno na gram tkáně, přítomný v nejvyšším množství. Stále ovšem není úplně stanoveno, jaké by de facto normální hodnoty selenu měly být. Předpokládá se, že zlepšení saturace organizmu selenem může příznivě ovlivnit některé patologické procesy. Existují práce, podle nichž substituce selenu vykazuje pomocný efekt v léčbě lehčích forem endokrinní orbitopatie. Jiní autoři odkazují na další podstatný fakt, a to že suplementace selenem bude účinná jen u pacientů s jeho deficitem. Co je naopak jisté, je to, že saturace české a dá se předpokládat, že pravděpodobně i slovenské populace selenem nebude př́liš uspokojivá, spíše naopak. A tak se kruh našich úvah uzavírá.

Sotakova přehledná práce velmi fundovaně vyhodnocuje aktuální míru poznatků týkajících se prínosu podávání selenu nemocným s rưznou tyreoidální patologií. Nečiší z ní ani nepatřičný optimizmus, ale autor doplňkovou léčbu selenem na druhé straně zcela nezatracuje. Internista či dokonce endokrinolog zde dostává možnost nahlédnout ve zkratce na současný "state of art", což ocení v každodenní praxi.

\section{Literatura}

1. Kvíčala J, Jiránek J, Němeček J et al. Deficit selenu v populaci západních Čech. IGA MZČR 2006; Č. 7763-3 a 7820-4. Dostupné z WWW: $<$ http://docplayer.cz/18002859-Deficit-selenu-v-populaci-zapadnich-eech.html>.

2. Winther $\mathrm{KH}$, Bonnema $\mathrm{S}$, Hegedüs $\mathrm{L}$. Is selenium supplementation in autoimmune thyroid diseases justified? Curr Opin Endocrinol Diabetes Obes 2017; 24(5): 348-355. Dostupné z DOI: <http://dx.doi. org/10.1097/MED.0000000000000356>.

3. Rotondo Dottore G, Chiarini R, De Gregorio M et al. Selenium rescues orbital fibroblasts from cell death induced by hydrogen peroxide: another molecular basis for the effects of selenium in graves' orbitopathy. Endocrine 2017; 58(2): 386-389. Dostupné z DOI: <http://dx.doi. org/10.1007/s12020-016-1226-9>.

4. Ventura M, Melo M, Carrilho F. Selenium and Thyroid Disease: From Pathophysiology to Treatment. Int J Endocrinol 2017; 2017:1297658. Dostupné z DOI: <http://dx.doi.org/10.1155/2017/1297658>.

doc. MUDr. Zdeněk Fryšák, CSc. $\square$ zdenek.frysak@gmail.com

III. interní klinika - nefrologická, revmatologická a endokrinologická LF UP a FN Olomouc

www.fnol.cz

Doručeno do redakce 25. 8. 2017 